\title{
A Study of the Formation of Innovative Clusters As Growth Poles In the Regions of Kazakhstan
}

\author{
Anel A. Kireyeva $^{a i}$, Saken S. Yespayev \\ ${ }^{a}$ PhD, Department of Regional Development, Institute of Economics MES RK, Almaty, Kazakhstan \\ ${ }^{b}$ Dr. of Economics, Director, Institute of Economics MES RK, Almaty, Kazakhstan
}

\begin{abstract}
The aim of this resarch is to examine the level of innovative process of national economy and to reveal the essence of the cluster approach and indicators of innovative development. Keeping with the previous literature, the present study is determined by the novelty of the problem, concerning the formation and development of innovative clusters as growth poles, as well as large specifics of problems in the framework of use of innovative potential. The study employs method of monitoring of innovative processes in regions; we use method of rating estimation of innovative competitiveness of the region, based on a complex of indicators characterizing the innovation potential of the region: innovative activity and innovative susceptibility. An analysis was showed that Kazakhstan's regions have substantial differences in the groups of regions for most of the indicators have presented form a tightly located clusters and in the ratings of innovative susceptibility and innovative activity.
\end{abstract}

Key Words: Cluster, Innovative Cluster, Regional Development.

JEL Classification: $O 31, R 11, R 12$

\section{C) 2014 Published by SSBFNET}

\section{Introduction}

The relevance of the problem is caused by occurring in the world and in our country globalization processes in economic development are directed on need for considerable economic, social and innovative and technological changes. In 2013-2014 the space of Kazakhstan will develop with really narrow level of opportunities caused by objective factors and barriers of development. The adequate choice of priorities of policy of the state is capable to strengthen influence of positive factors and to soften influence of barriers. But the speed of innovation growth and increase of competitiveness of national economy will depend on this choice.

Thus, will it to be possible to reduce from these barriers with the first challenge is to understand general patterns and trends territorial development. The second challenge is to highlight of objective and subjective conditions and

${ }^{i}$ Corresponding author. 
Kireyeva \& Yespayev /International Journal of Research in Business and Social Sciences Vol3 , No1, 2014. ISSN: $2147-4478$

opportunities for improving the competitiveness of the national economy. The third challenge is to create and develop a zone of innovative development, which are capable to transfer innovations at the periphery of the country.

The answer to these challenges will be able to find a cluster approach - organizational model that allows to concentrate its resources and to build partnerships. All this causes relevance of development of theoretical and methodological approaches to formation of ways of innovative development of territories of Kazakhstan within cluster initiatives.

In the preceding studies on the theory of the structure and the efficient organization of economic space based on the "growth poles" or on the "agglomeration effect" (i.e. predominating and strongest developing), which take the diffusion of growth is expected to occur towards the surrounding region (Romer 1986; Krugman 1991; Steiner and Hartmann 1998; Bergman and Feser 1999).

So, Kazakhstan according to these conceptual views is in transition from benefits of "first nature" based on the factors of natural resources, to the priorities of the "second nature" based on the agglomeration effect, human capital, infrastructure and institutional environment. The factors of "second nature" must play a key role in the formation of innovative clusters. Because agglomeration is a set of geographically concentrated organizations are united by a certain sphere of activity.

In our opinion, the strategic plan of the formation of innovation clusters, must be identified so-called "growth poles", the development of which will be accompanied by a multiplicative effect for the innovation base of the territory. The regions of Kazakhstan need to diversify their production structure. The main task for the diversification of the regions is the search for new industries (based on innovation), which should be developed. We think that this task can solve a cluster approach to the placement of production facilities with a view of the agglomeration effect. So, we offer at the first stage of expansion of global competitive advantages of Kazakhstan's economy in the traditional economic sectors (energy, industry, processing of natural resources). Simultaneously, should create the conditions for the formation of a number of innovative clusters through "growth poles". Such an approach would make a breakthrough in increasing the global competitiveness of the economy on the basis of transition to a new technological base (information, biotechnology etc).

The empirical evidence confirms the existence of knowledge spillovers within regions, though the evidence on interregional knowledge spillovers is scarce and mixed (Frenken et al. 2010). Positive effects of knowledge spillovers have been found within and between regions, as well as the support of the most innovative active regions (Leontiev 1997; Hmeleva 2012; Untura 2012).

Therefore, we propose to form of innovative clusters with regard to the agglomeration effect. So, due to the high level of influence on the regional economy innovative clusters represent as growth poles, the impact of which will lead to the maximum return not only for the region but also in the whole country.

The present study is aimed to analyze the of the level of innovation process of national economy, and to develop new approaches of the formation and development of innovative clusters in Kazakhstan in the regional context, to the need of formation of innovation clusters as growth poles on the basis of method of monitoring and method of ranking of the process of innovative development of regions. 
Kireyeva \& Yespayev /International Journal of Research in Business and Social Sciences Vol3 , No1, 2014. ISSN: $2147-4478$

The study is divided into the following sections. The Section 2 proposes to consider the theoretical aspects of the formation of innovative clusters in the regional context. Section 3 sets the methods of monitoring and ranking of the level of innovation potential in the regions of Kazakhstan. Section 4 is a concluding part.

\section{Theoretical aspects of the formation of innovative clusters in the regional context}

A constitutive element of this study of spatial development is a complete overview of the previous works. Long ago the regional science conclusively showed that the spatial inequality emerges as an objective effect of the competitive advantages concentration in certain territories and lack of these advantages in others (Kireyeva and Nurlanova 2013). There is an opinion that established a stable consensus spatial development: it may not be uniform.

Today there are some basic directions of management of economic development of territorial systems. We offer the following types of the directions:

1) "territorial and spatial" development which is based on a basis of search of the best placement of competitive (advanced) production and the enterprises concerning sources of raw materials, energy, each other, and also consumers within separate territories (Kireyeva and Nurlanova 2013);

2) "complex" development, which is based on formation of system approach to management of areas with different levels of economic development and functional status of the business within the territorial units (Barmasheva et al. 2008);

3) "point-innovative development" the essence of which is to review and dissemination narrowly spatial organization of innovative production in the framework of interconnected territorial groups (Yespayev and Kireyeva 2013).

Thus, the last from the directions is important within our research. As it becomes obvious that just like the path of cluster development improves the conditions for diffusion of innovations in the regional context.

So, there are two ideas behind the principal study questions and hypotheses that are the subject of this research. Thus, this study will try to expand researches in the field of these two ideas, and also to solve the problem of the formation and development of innovative clusters in the regional context.

First, it is the theory of "agglomeration effect" by Krugman (1991) - main factor of growth is the accumulation of industrial activity in certain geographically interconnected regions, which gives an advantage to enterprises due to the increase of their size or from positive externalities arising due to the market presence of other enterprises. Krugman (1991) considered that primordial uneven distribution of production in the transition to the equilibrium leads to the formation of agglomerations. The emergence of agglomerations he associates with the concept of increasing returns to scale. Ultimately, uneven development of regions supports agglomeration of industrial activity areas. Therefore Krugman (1991) proposed to create clusters not as a fixed flow of goods and services, but as a dynamic structure based on knowledge creation and innovation.

This theory is further supplemented and developed by Romer (1986). According to him, the main factor of the development in theory of "innovative growth" is the accumulations of productive activities in certain regions which can be united by a certain sphere of activity (Romer 1986). Structural and technological shifts are occurring in the economy of the countries and enterprises (innovative process) - innovative stage in the development of management, 
Kireyeva \& Yespayev /International Journal of Research in Business and Social Sciences Vol3 , No1, 2014. ISSN: $2147-4478$

they cause the phenomenon of the so-called "new growth theory". Such innovative orientation is becoming the main characteristic of clusters, because it determines their competitiveness.

Other researchers have considered clusters as "growth zones" or "growth poles", which can be geographically concentrated, typically inside the agglomeration area (Steiner and Hartmann 1998). The clusters aren't only related and supporting industries, but rather related and supporting institutions, which become more competitive on the basis of their association (Bergman and Feser 1999).

All these theories aren't competitors, but they complement each other. In essence, these theories are applied in parallel and in various combinations, depending on the characteristics of the national economy. It should be noted that all these theories work on all levels - from the world's cities and large agglomerations, to regional and local centers. So, the diffusion of innovations is distributed in two ways:

1) the first way - by the hierarchical system of cities (i.e. from the most big cities to smaller cities in size and status);

2) the second way - by the system from centers in the surrounding areas (i.e. "spilling" the neighboring territory, which is especially intensively develops in the limits of the largest agglomerations).

Secondly, it's the study of processes of territorial and spatial concentration of the economy, including in the framework of the "new economic geography" (Fujita and Krugman 2004). The fundamental cause of economic inequality is a process that has long considered the concentration of economic activity in those places which have comparative advantages, to reduce business costs.

In our opinion, the theory of "agglomeration effect"(Krugman 1991) and the theory of "innovative growth" (Romer 1986) show how important a role in the development of the country is played by the city: it is not only the "reference frame" of settlement, but the "engines" translation impetus of innovation at the periphery. It is these two theoretical sights are the basis of our research in the field of formation of cluster structures in the regional context.

So, one should highlight the hypothesis that the formation that formation and development of innovative cluster structures should begin from "growth poles"(i.e. they will be played the role of translator's innovations at the periphery of the country). This approach provides an effective transformation of inventions into innovations, and innovation in competitive advantages of the cluster.

\section{Methods}

The methods used in this research are aimed at studying the process of innovative development of regions of Kazakhstan. The study involves the use of general economic indicators, analysis methods development of a region, to determine its economic profile and place in the economic complex of the country. In accordance with diverse backgrounds to study the process of innovative development of regions can use certain methodological approaches (Balabanova 2009; Koshkarov 2012). Such methodological approaches will help to define the most competitive territory in which it is possible to form effective of innovative clusters.

On the basis of the methods used to assess possible to do the following: to establish the compliance of the existing level of innovation development of a region; to determine the conformity of the productive forces of the region with its economic conditions; to identify the growth pole for broadcast innovation. 
Kireyeva \& Yespayev /International Journal of Research in Business and Social Sciences Vol3 , No1, 2014.

ISSN: $2147-4478$

The experience shows that as important indicators that can assess the existing level of innovation development of regions can be used the following indicators (used in this study):

- gross regional product (GRP) and the rate of growth of the gross regional product;

- level of labor productivity and the number of employed population in the regions;

- total volume of innovative products in the regional economy, including per capita and the dynamics of these indicators;

- research and development (R\&D) costs and expenditure on technological innovation;

- derivatives and other indicators that reflect the specific characteristics of the innovative potential of the region.

3.1. Method of monitoring of innovative processes in regions

Innovation "is the object embedded in production as a result of the carried out research or discovery, qualitatively different from the previous analogue" (Utkin and Morozova 1996:10). It is obvious, that it is very important to explore regional context of the innovative process. The economic geography has placed agglomeration, knowledge spillovers, regional economic growth and spatial context at the center of its research (Feldman 2000). The basis of the idea by Feldman: "the concept of location is defined as a geographical unit that facilitates interaction and communication, the search for knowledge, and coordination tasks" (Feldman 2000: 373).

Certain empirical evidence shows the existence of knowledge spillovers within regions, but the evidence of the interregional relations of knowledge spillovers is still not investigated (Frenken et al. 2010). Innovative potential of the region is a comprehensive innovative resource, providing the intensive development of economic entities in the region and facilitating the obtaining of income. In this context, it seems appropriate to define the dependence of the innovative capacity of the regions of indicators of innovative activity and innovative susceptibility. So, it is interesting analysis of innovative processes in regions.

Taking into account the fact that the ultimate result of economic activities of the regions is gross regional product (GRP), thus the evaluation of innovative processes should begin with the analysis of GRP.

For a start, Kazakhstan occupies $2.724 .900 \mathrm{sq} \mathrm{km}$ (thus being the 9th largest country of the world). Unlike other countries, Kazakhstan is characterized by: huge territories, low population density and highly dispersed production potential. Administratively Kazakhstan is comprised of 14 regions and 2 cities of republican subordination. So, Figure 1 illustrates the dynamics of GRP for 16 regions of Kazakhstan. 
Kireyeva \& Yespayev /International Journal of Research in Business and Social Sciences Vol3 , No1, 2014.

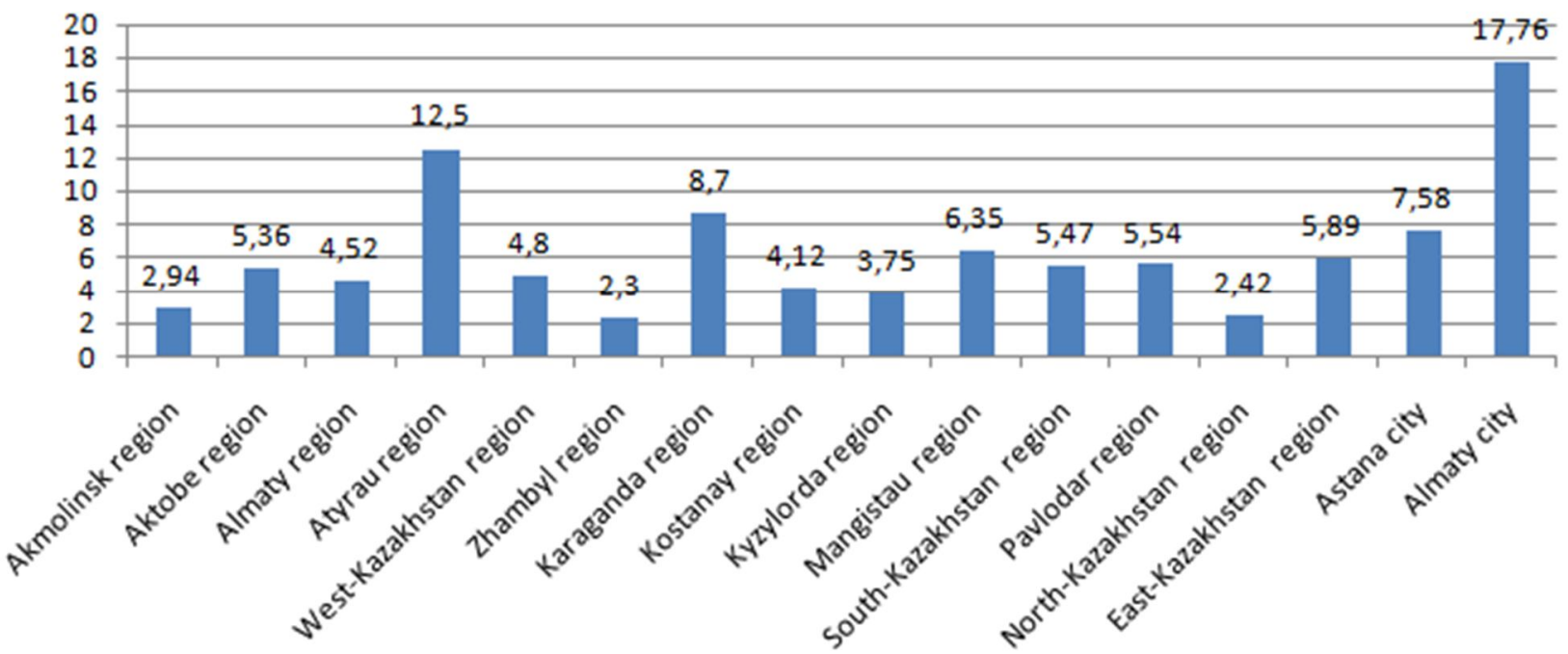

Fig. 1. Dynamics of GRP in theregions of Kazakhstan in $2012(\%)$

As shown Figure 1, the largest contribution to GRP made by Almaty city (17,76\%), Atyrau region (12,5\%), Karaganda region (8,7\%), Astana city (7,58\%) and Mangistau region (6,35\%). The lowest share in GRP demonstrated by such regions as Akmolinsk (2,94\%), Zhambyl (2,3\%) and North-Kazakhstan (2,42\%).

According to the theory of "innovative growth" by Romer (1986), main factor of economic growth is the increase in investments in research and development (R\&D). The term R\&D or Research and Development refers to a specific group of activities within a business. $R \& D$ indicator is the most important element in innovation processes are the creative minds. The new regional innovation economics it is argued that a stimulating and supportive regional environment facilitates their innovation activities causing their productivity to differ systematically inter-regionally (Desrochers, 2001). Hence, the R\&D employees can be considered the necessary resource for innovative processes, while the factors presented below represent supportive elements (Broekel and Brenner, 2011).

Thus, Kazakhstan is presented as one of the most highly educated country in the world, but in terms of economic development is a little behind the most countries. From a quantitative point of view the scientific potential of qualified specialists does not meet the needs of innovative development. Data on the number of staff employed in R\&D can be seen in Table 1. 
Kireyeva \& Yespayev /International Journal of Research in Business and Social Sciences Vol3 , No1, 2014. ISSN: $2147-4478$

Table 1: Number of enterprises engaged in R\&D in the regions of Kazakhstan 2008-2012

\begin{tabular}{lllllll}
\hline & $\begin{array}{l}\mathbf{2 0 0 8}, \\
\text { pcs }\end{array}$ & $\begin{array}{l}\mathbf{2 0 0 9}, \\
\mathbf{p c s}\end{array}$ & $\begin{array}{l}\mathbf{2 0 1 0}, \\
\mathbf{p c s}\end{array}$ & $\begin{array}{l}\mathbf{2 0 1 1}, \\
\mathbf{p c s}\end{array}$ & $\begin{array}{l}\mathbf{2 0 1 2}, \\
\mathbf{p c s}\end{array}$ & $\begin{array}{l}\mathbf{2 0 1 2} \text { compared to } \\
\mathbf{2 0 0 8} \text { (in \%) }\end{array}$ \\
\hline Region of Kazakhstan & $\mathbf{4 2 1}$ & $\mathbf{4 1 6}$ & $\mathbf{4 2 4}$ & $\mathbf{4 1 2}$ & $\mathbf{3 4 5}$ & $\mathbf{8 1 , 9 5}$ \\
Akmolinsk region & 8 & 7 & 7 & 8 & 9 & 112,50 \\
Aktobe region & 16 & 15 & 16 & 18 & 16 & 100,00 \\
Almaty region & 12 & 7 & 10 & 8 & 7 & 58,33 \\
Atyrau region & 11 & 12 & 12 & 9 & 9 & 81,82 \\
East-Kazakhstan region & 35 & 34 & 33 & 36 & 34 & 97,14 \\
Zhambyl region & 11 & 12 & 10 & 7 & 8 & 72,73 \\
West-Kazakhstan region & 10 & 10 & 10 & 9 & 15 & 150,00 \\
Karaganda region & 40 & 29 & 28 & 29 & 26 & 65,00 \\
Kostanay region & 13 & 14 & 15 & 13 & 14 & 107,69 \\
Kyzylorda region & 7 & 9 & 14 & 23 & 7 & 100,00 \\
Mangystau region & 7 & 6 & 8 & 8 & 7 & 100,00 \\
Pavlodar region & 11 & 10 & 9 & 11 & 11 & 100,00 \\
North-Kazakhstan region & 5 & 5 & 5 & 3 & 3 & 60,00 \\
South-Kazakhstan region & 11 & 10 & 9 & 9 & 11 & 100,00 \\
Astana city & 41 & 43 & 42 & 41 & 49 & 119,51 \\
Almaty city & 183 & 195 & 196 & 180 & 119 & 65,03 \\
\hline
\end{tabular}

Source: Statistical Yearbook of the Republic of Kazakhstan by the Agency for statistics

According to these data, for the period 2008-2012 there is a reduction in the number of enterprises engaged in R\&D for $81,95 \%$. Reduction in the number of enterprises engaged in R\&D, means that lost an important place in the links of production and science, as well as decreased the shortest way of introduction of scientific results into production.

Besides, for the period 2008-2012 is the greatest decrease in the number of organizations engaged in R\&D show Almaty city $(58,33 \%)$, North-Kazakhstan region $(60,00 \%)$ and Karaganda region $(65,00 \%)$. There is an objective reason for such a substantial reduction of the scientific enterprises: financial situation of many industrial enterprises does not allow for the support of scientific and design studies (although the relevance of such studies is very affects the competitiveness of production in the field of innovation).

However, some regions of Kazakhstan during the analyzed period 2008-2012 demonstrate a high level of scientific potential by increasing the number of enterprises engaged in R\&D. In particular: West-Kazakhstan region (150,00\%), Akmolinsk region (112,50\%), and Astana city (119,51\%). Certainly in Astana city increase in the number of research organizations is connected with forthcoming international exhibition "Astana EXPO-2017".

The regional economic policy should focus on creating of enabling environment for an innovation stage in the underdeveloped regions, such as to create of educational and scientific centers. Thus, innovative activity can be maintained by the creation and development of such structures as innovative clusters on the basis of industrial parks, technology incubators, and data banks of innovation (Yespayev and Kireyeva 2013). 
Kireyeva \& Yespayev /International Journal of Research in Business and Social Sciences Vol3 , No1, 2014. ISSN: $2147-4478$

So, we conducted a study of innovative processes in the regions in order to identify the points of growth, which have the necessary conditions for the formation of innovation clusters ( i.e. they have a sustainable system for the dissemination of new technologies and knowledge, so-called technological network based on the joint scientific or production base).

Generalization it's necessary to develop the innovative infrastructure of the region by strengthening the knowledgeintensive industry, and to improve of the innovation capacity of the economy through the centers for innovation generation (techno parks, techno polis, laboratories and research units). Innovative clusters become a kind of a "platform", which can accelerate the process of innovation, and cluster participants develop such benefits as innovative susceptibility and innovative activity.

\subsection{Method of ranking by the level of innovative susceptibility and innovative activity}

In our study, taking into account the existing methods of estimating, we have proposed a complex method of ranking, taking into account territorial factors and sector conditions for regional development. The basis of the proposed method is the calculation of consolidated integral indicator of innovation attraction, which is formed into account a number of special factors based on a complex of indicators: innovative activity and innovative susceptibility.

The rating methodology can help in verification methods, i.e. select "cumulative conditions", in the form of indicators reflecting the development of new sectors of the economy, accommodation on the territory of the state corporations, activation of small business and other (Untura 2012). Leontiev conducted the analysis of innovative factors of the region development by the method of input-output balances (1997). Granberg proposed analysis of innovative activity of regions by evaluating of the structure and dynamics of the gross regional product (Granberg et al. 1998).

In order to build ratings was chosen set of parameters, which determine the level of innovative development of regions and monitoring of the state statistics (Agency of the Republic of Kazakhstan on statistics), as well as developed the mathematical apparatus of receipt of the aggregated ratings. In the ranking are applied indicators of the innovative development of region, which are divided into two groups:

1) factors describing the level of innovative susceptibility of the region;

2) factors describing the level of innovative activity of the region.

The policy of innovative development of the "poles growth" by Krugman (1991) with almost total disregard stimulation for the equalization policy dominates until now. As a result the inequality of development zones of the modernization and underdeveloped periphery has grown up. So, analysis of ranking regions in terms of innovative activity will help determine the spatial priorities of innovative development of the national economy.

Thus, the total lacks of all existing methods of the analysis of innovative activity are study and measure, but need research the economic situation and its consequence. The proposed alternative direction is connected with the phase of the analysis of innovative factors of regional development.

So, we highlight the hypothesis that the causes of all the changes occurring in the development of the regions depend on two sources: innovative activity and innovative susceptibility. 
Kireyeva \& Yespayev /International Journal of Research in Business and Social Sciences Vol3 , No1, 2014.

ISSN: $2147-4478$

Pay attention to the fact that in the ranking used relative units, which reflected the efficiency of innovation activities, both in terms of process (innovative activity), and from the point of view of achieving the delivered result (innovative susceptibility). Ranking calculation need to begin with the formula, which determined the "leader- region" with maximum value of the index, this is taken for $100 \%$. Further against the leader of the appropriate options other regions are translated in percentage terms with the formula below (Eq.1):

$S i=(X i / X \max ) * 100 \%(1)$

where $\mathrm{i}$ - number of region; Xi - value of the parameter for ith region; Xmax - parameter value for the "regionleader"; $\mathrm{Si}$ - percentage of the value of the parameter in ith region to region-leader.

Innovative activity presents three indicators: research and development costs; expenditure on technological innovation; innovative production output per capita.

Innovative susceptibility presents three indicators: labor productivity; capital productivity; ecological compatibility of production.

Accordingly ratings of innovative susceptibility and innovative activity of the regions will be determined by the formulas (Eq.2) and (Eq.3):

$I s=(S d+S f+S e) / 3$

where Is - rating estimation of innovative susceptibility of the region; Sd - percentage of labor productivity in the region's economy to the maximum value of the aggregate; $\mathrm{Sf}$ - percentage of bestowal fixed assets in the economy of the region to the maximum value of the aggregate; $\mathrm{Se}$ - percentage of sustainability of the regional economy to the maximum value of the aggregate.

$I a=(S a+S b+S c) / 3(3)$

where Ia - rating estimation of innovative activity of the region; $\mathrm{Sa}$ - percentage of expenditure on research and development per 1 employee to the maximum value of the aggregate; $\mathrm{Sb}$ - percentage of expenditure on technological innovation per 1 employee to the maximum value of the aggregate; Sc - percentage of the volume of release of innovative production on capita of the region to the maximum value of the aggregate.

The method based on the ranking of the territories (regions) can detect their characteristics, advantages and disadvantages. Dignity ratings are the facts that for the final comparison are used the initial data, as well as are assigned normalized grades, which characterized the indicator in a certain region of the country. So, taking into account the variety of methods of processing initial data, we offer alphanumeric scale for rating of innovative development of regions in Table 2. 
Kireyeva \& Yespayev /International Journal of Research in Business and Social Sciences Vol3 , No1, 2014.

Table 2: Indexes rating of innovative development of regions and their interpretation

\begin{tabular}{|c|c|c|}
\hline Grade & Rating score & Interpretation \\
\hline \multicolumn{3}{|c|}{ Group $\mathrm{A}$ - regions leaders } \\
\hline $\mathbf{A}++$ & from 90 to 100 & Super high level of innovative development \\
\hline $\mathbf{A}+$ & from 80 to 90 & A very high level of innovative development \\
\hline $\mathbf{A}$ & from 70 to 80 & High level of innovative development \\
\hline \multicolumn{3}{|c|}{ Group B - regions with average data } \\
\hline $\mathbf{B}++$ & from 60 to 70 & Level of innovative development above average \\
\hline $\mathbf{B}+$ & from 50 to 60 & Average level of innovative development \\
\hline B & from 40 to 50 & Satisfactory level of innovative development \\
\hline \multicolumn{3}{|c|}{ Group C - regions with low data } \\
\hline $\mathrm{C}++$ & from 30 to 40 & Level of innovative development below average \\
\hline $\mathbf{C}+$ & from 20 to 30 & Low level of innovative development below average \\
\hline C & from 10 to 20 & Very low level of innovative development \\
\hline \multicolumn{3}{|c|}{ Group D - regions with poor data } \\
\hline D & from 0 to 10 & Unsatisfactory level of innovative development \\
\hline
\end{tabular}

Source: Complied by authors

Pay attention to the fact that all the initial data in the ranking aren't absolute, but relative measurement units, which reflected the efficiency of innovation activities, both in terms of process (innovative activity), and in terms the (innovative susceptibility). Initial data for the rating were taken from the statistical data of the Republic of Kazakhstan. Innovative susceptibility is the ability of the region to detect innovation in the information field, to distinguish the individual characteristics of innovation, to identify and take innovation to use in order to improve its competitiveness (Maslennikova 2010). Therefore, innovative susceptibility is a process of evaluating innovation, initiation of its adoption, implementation of innovations (transformation of innovations into the usual and the predictable structure). So, innovative susceptibility represents a group of three indicators: labor productivity, capital productivity (return on fixed assets) and environmental friendliness of production.

In accordance with an alphanumeric scale and the initial data (Appendix A, Appendix B) the indexes of innovative susceptibility for all regions of Kazakhstan are shown in Table 3. 
Kireyeva \& Yespayev /International Journal of Research in Business and Social Sciences Vol3 , No1, 2014. ISSN: $2147-4478$

Table 3: Rating by the level of innovative susceptibility in regions of Kazakhstan for 2010 and 2012

\begin{tabular}{llllll}
\hline No. & Region of Kazakhstan & $\mathbf{2 0 1 0}$ & 2012 & \\
& Rating score & Grade & Rating score & Grade \\
\hline 1 & Akmolinsk region & 16,66 & $\mathrm{C}$ & 29,66 & $\mathrm{C}+$ \\
2 & Aktobe region & 19,05 & $\mathrm{C}$ & 29,68 & $\mathrm{C}+$ \\
3 & Almaty region & 19,58 & $\mathrm{C}$ & 32,32 & $\mathrm{C}++$ \\
4 & Atyrau region & 47,84 & $\mathrm{~B}$ & 57,47 & $\mathrm{~B}+$ \\
5 & West-Kazakhstan region & 21,04 & $\mathrm{C}+$ & 29,40 & $\mathrm{C}+$ \\
6 & Zhambyl region & 19,45 & $\mathrm{C}$ & 32,93 & $\mathrm{C}++$ \\
7 & Karaganda region & 15,19 & $\mathrm{C}$ & 42,64 & $\mathrm{~B}$ \\
8 & Kostanay region & 45,84 & $\mathrm{~B}$ & 35,64 & $\mathrm{C}++$ \\
9 & Kyzylorda region & 25,68 & $\mathrm{C}+$ & 36,74 & $\mathrm{C}++$ \\
10 & Mangistau region & 20,44 & $\mathrm{C}+$ & 41,65 & $\mathrm{~B}$ \\
11 & South-Kazakhstan region & 23,82 & $\mathrm{C}+$ & 35,29 & $\mathrm{C}++$ \\
12 & Pavlodar region & 19,69 & $\mathrm{C}$ & 34,68 & $\mathrm{C}++$ \\
13 & North-Kazakhstan region & 18,94 & $\mathrm{C}$ & 36,31 & $\mathrm{C}++$ \\
14 & East-Kazakhstan region & 21,26 & $\mathrm{C}+$ & 34,40 & $\mathrm{C}++$ \\
15 & Astana city & 31,56 & $\mathrm{C}++$ & 39,21 & $\mathrm{C}++$ \\
16 & Almaty city & 66,64 & $\mathrm{~B}++$ & 81,19 & $\mathrm{~A}+$ \\
\hline
\end{tabular}

Source: Complied by authors

Innovative activity of the region reflects the ability of the territorial industrial systems to the perception of the scientific-technical and social innovations in production, and their practical implementation in technical and socioeconomic systems (Voronina 1998). So, innovative activity is purposeful activity of the region regarding creation, development and production of qualitatively new types of equipment, subjects of labor, intellectual property and innovative technologies. Innovative activity is a group of three indicators: research and development costs; expenditure on technological innovation; innovative production output per capita.

The starting point is that there is little research that has analyzed the innovative activity of regions in relation to regional variables, with the result that there is no clear distinction between the effects attributable to the firm and the region (Hmeleva 2012). In accordance with an alphanumeric character scale and the initial data (Appendix A, Appendix B).The indexes of innovative activity for all regions of Kazakhstan are shown inTable 4 .

In the result of the ranking shows that the central and eastern zones of Kazakhstan are the most developed in terms of innovative capacity. In these regions, there are a large number of large enterprises of heavy industry, in particular, coal-mining, metallurgy, oil, etc. In addition, these regions have the most developed of the electricity and engineering infrastructure. The regions of the southern zone have a fairly low level of innovation development due to the smaller number of large industrial enterprises and low security by resources. 
Kireyeva \& Yespayev /International Journal of Research in Business and Social Sciences Vol3 , No1, 2014. ISSN: $2147-4478$

Table 4: Rating by the level of innovative activity in regions of Kazakhstan for 2010 and 2012

\begin{tabular}{|c|c|c|c|c|c|}
\hline \multirow[b]{2}{*}{ No. } & \multirow[b]{2}{*}{ Region of Kazakhstan } & \multicolumn{2}{|l|}{2010} & \multicolumn{2}{|l|}{2012} \\
\hline & & Rating score & Grade & Rating score & Grade \\
\hline 1 & Akmolinsk region & 5,85 & $\mathrm{D}$ & 8,18 & $\mathrm{D}$ \\
\hline 2 & Aktobe region & 15,89 & $\mathrm{C}$ & 27,11 & $\mathrm{C}+$ \\
\hline 3 & Almaty region & 1,52 & $\mathrm{D}$ & 3,21 & $\mathrm{D}$ \\
\hline 4 & Atyrau region & 14,85 & $\mathrm{C}$ & 28,18 & $\mathrm{C}+$ \\
\hline 5 & West-Kazakhstan region & 6,46 & $\mathrm{D}$ & 48,61 & B \\
\hline 6 & Zhambyl region & 7,27 & $\mathrm{D}$ & 8,67 & $\mathrm{D}$ \\
\hline 7 & Karaganda region & 6,58 & $\mathrm{D}$ & 9,34 & $\mathrm{D}$ \\
\hline 8 & Kostanay region & 5,54 & $\mathrm{D}$ & 5,78 & $\mathrm{D}$ \\
\hline 9 & Kyzylorda region & 11,73 & $\mathrm{C}$ & 3,45 & $\mathrm{D}$ \\
\hline 10 & Mangistau region & 31,71 & $\mathrm{C}+$ & 31,51 & $\mathrm{C}++$ \\
\hline 11 & South-Kazakhstan region & 2,71 & $\mathrm{D}$ & 6,19 & $\mathrm{D}$ \\
\hline 12 & Pavlodar region & 38,65 & $\mathrm{C}+$ & 38,78 & $\mathrm{C}++$ \\
\hline 13 & North-Kazakhstan region & 2,35 & $\mathrm{D}$ & 1,37 & $\mathrm{D}$ \\
\hline 14 & East-Kazakhstan region & 48,62 & B & 26,23 & $\mathrm{C}+$ \\
\hline 15 & Astana city & 20,58 & $\mathrm{C}+$ & 36,19 & $\mathrm{C}++$ \\
\hline 16 & Almaty city & 37,22 & $\mathrm{C}++$ & 36,21 & $\mathrm{C}++$ \\
\hline
\end{tabular}

Source: Complied by authors

Thus, Almaty city confirms its status of leader in terms of innovative development. This city possesses the most powerful labor, consumer, transport and infrastructural potential, as is the financial capital of Kazakhstan. However, it should be borne in mind that the excellent financial performance Almaty city is provided by the fact that there are central offices of most of the major companies.

The results showed in a visual form that there are innovative - technological differences between the regions of Kazakhstan. The groups of regions for most of the indicators have presented form a tightly located clusters around of four groups of values: locomotive regions, growth poles regions, prospective regions and problem regions.

The group of locomotive regions is characterized by a high level of socio-economic development, the availability of centers of science and high technologies, and formed strategic initiative, which is of importance for the entire country (Almaty city and Atyrau region). Within the group are distinguished centers of financial and economic values.

The main difficulty of growth poles regions with raw type is the lack of quality of urban environment. In our opinion, this group of regions consists mainly of old-industrial regions with high pre-crisis level of industrial development, technological progress and intensification of production (West-Kazakhstan region, Astana city, Pavlodar region and other). The regions with developed manufacturing industries have classified as developed regions based on manufacturing industries; regions specializing in manufacturing industry combined with the extractive sector have classified as developed regions with the support of the mining industry. The majority of the regions included in these two type are developed through export-oriented industries: metallurgy, chemical and petrochemical industry. 
Kireyeva \& Yespayev /International Journal of Research in Business and Social Sciences Vol3 , No1, 2014. ISSN: $2147-4478$

The prospective regions with support on the manufacturing and extractive industry in its development should strive to deepen processing of raw materials; they should abandon from the single-industry, and thus improve the competitiveness of industries (Karaganda region, Aktobe region, East-Kazakhstan region and other). At the same time, attention should be given to the development, production and engineering services. A number of large cities-centers of this type will be able to compete with the capitals of developed regions with diversified economy as translators of innovation.

The group of problem regions within the meaning of practically identical with the less developed, the depressive regions and extremely special regions. However, the latter group is much wider: it includes the regions of Northern and Eastern Kazakhstan, and individual regions of the South region. So, in these regions are located the majority of single-industry cities. The data of the territorial entities were the most affected in terms of changes of the course of economic development and the subsequent sharp decline in production.

In this regard, there are certain possibilities for combining the efforts of the metallurgical, coal-mining, manufacturing, engineering and other companies, aimed at creating conditions for further development of the cluster groups. So, in the near future propose the creation of the following clusters:

- "Information technology and electronic commerce" cluster (in Astana city and Almaty city) - innovative project, which is aimed at creation and development of innovative, information and communication products.

- "Coal-energy" cluster (in Pavlodar region and North-Kazakhstan region) - innovative project is aimed at uniting of mining, generating and processing industries on a coal mining. Such an industrial structure of the cluster will bring to a qualitatively new level of a coal mining, production and consumption.

- "Technologies of metalworking" cluster (in Karaganda region and East-Kazakhstan region) innovative project, which includes metalworking enterprises, welding companies, manufacturers of machinery and equipment, construction companies and other related sectors.

- "Technologies of petrochemical processing" cluster (in Atyrau region and West-Kazakhstan region) - innovative project is aimed to modernization of the enterprises with introduction of innovative technologies for deep processing of heavy oil, and also the rests of refineries and petrochemical plants.

An important condition for the formation of market innovation system is the transition to the balanced development of all regions of the country, i.e. the formation of zones of advanced development, capable to translate innovation at the periphery of the country.

Generalization: it's important to maintain the regions with high innovative activity and innovative susceptibility, as they are growth poles and they will play the role of translator's innovations at the periphery.

\section{Results}

The results in Fig. 1 shown that the first place and the most high dynamics shows Almaty city - 17,76 \%, Atyrau region according to this data takes the second place $-12,5 \%$. Then there are the following regions: Karaganda region $(8,7 \%)$, Astana city (7,58\%) and Mangistau region (6,35\%). The lowest share in GRP demonstrated by such regions as Akmolinsk (2,94\%), Zhambyl (2,3\%) and North-Kazakhstan (2,42\%). The stable indicators share of GRP of Almaty 
Kireyeva \& Yespayev /International Journal of Research in Business and Social Sciences Vol3 , No1, 2014. ISSN: $2147-4478$

city in the general structure caused by the development of the sphere of services, which includes telecommunications, financial, insurance and other industries. In turn, the stable indicators share of GRP Atyrau region and Mangistau region is characterized by dynamic development of oil and gas industry. The greatest reduction in participation in proceedings of GRP shows in the Kostanay region (for 7\%), East-Kazakhstan region (for 5,5\%) and NorthKazakhstan region (for 5.1\%).

The results showed in a visual form that there are innovative - technological differences between the regions of Kazakhstan. The groups of regions for most of the indicators have presented form a tightly located clusters around of four groups of values: locomotive regions, growth poles regions, prospective regions and problem regions.In the result of the ranking shows that almost all the regions not included in the grade "A", except Almaty city by the level of innovative susceptibility. Regions with rating grade "B" is characterized by low economic efficiency research and development costs: the share of the produced innovative products is several times less than the share of internal research and development costs in the total volume. It's especially applies to the group of regions with grade "C" and "D", as the majority of regions of Kazakhstan were included in these grades. This in turn proves that the degree of innovative development is rather low in Kazakhstan.

\section{Conclusion}

This work marks a starting point for further research in the field of the formation and development of innovative clusters in the regional context. It provides some suggestions for improvement of future studies dealing with this subject. It also delivers innovation specific insights into the coherence between the city-centers and peripheral regions. On the basis of these research findings of this paper, the practical implications are listed below:

First, the theoretical part of this study shows the importance of theory "agglomeration effect" and "innovative growth", they aren't compete among themselves, but they complement each other. In essence, these theories are applied in parallel and in various combinations, depending on the characteristics of the national economy. In our opinion, these theories show how important a role in the development of the country is played by the city: it is not only the "reference frame" of settlement, but the "engines" translation impetus of innovation at the periphery. It is these two theoretical sights are the basis of our research in the field of formation of innovative clusters in the regional context.

Secondly, monitoring of the innovative process in the regions of Kazakhstan showed heterogeneity of innovative space. Over the past four years was registered a decline in the number of enterprises, $R \& D$, which is connected with the decrease of demand for innovations in the Kazakhstan economy. Therefore, regional policy should focus on creating of enabling environment for an innovation stage in the underdeveloped regions, such as to create of educational and scientific centers. So, innovative activity can be maintained by the creation and development of such structures as innovative clusters on the basis of industrial parks, technology incubators, and data banks of innovation. In between the centers and peripheral areas, there is movable area of the semi-periphery, which is more active and when a sudden change of conditions of development they can intercept functions of the centre. All this proves how important a role in the development of the country play "growth pole": it's not only the "reference point" to distribute, 
Kireyeva \& Yespayev /International Journal of Research in Business and Social Sciences Vol3 , No1, 2014.

ISSN: $2147-4478$

but it's the main "engine" to translate innovations at the periphery. Innovative clusters become a kind of a "platform", which can accelerate the process of innovation, and cluster participants develop such benefits as innovative susceptibility and innovative activity.

Thirdly,dependence of the territorial proximity of the various enterprises and organizations with aim to support a fullfledged innovation activity and innovative susceptibility to force understands clusters as foci of the innovation development in space. Therefore, innovative clusters become a kind of a "platform", which can accelerate the process of innovation, and cluster participants develop such benefits as innovative susceptibility and innovative activity. Because of conducted analysis and calculations, it can be concluded that this function can perform several large cities in the country with preserved scientific potential. In the case of improving the investment climate, they will be able to receive venture financing, including foreign. So, in such cities possible to create innovative clusters, this will develop the educational and scientific systems (quality universities and research structures) with an effective system of stimulating the scientific activity.

\section{ACKNOWLEDGEMENTS}

This study was supported by Institute of Economics of the Ministry of Education and Science of the Republic of Kazakhstan.

\section{References}

Bergman, E. M. and Feser, E. J. (1999).Industrial and Regional Clusters: Concepts and Comparative Applications. Regional Research Institute, West Virginia University

Balabanova, E.A. (2009). Methodical approaches to analysis and assessment of the level of socio-economic development of municipalities in the system of strategic planning (in Russian). Izvestia ISEA, 4, 144-146.

Barmasheva, L.V., Pavlov, M.E. and Kim, M. S. (2008).Problems of socio-economic development of the region in the Smolensk region (in Russian).EOF GOU MGIU, 56-65.

Broekel, T. and Brenner, T. (2011). Regional factors and innovativeness: an empirical analysis of four German industries.Annals of regional science, 47, 1, 169-194.

Desrochers, P. (2001).Local diversity, human creativity, and technological innovation.Growth Change, 32, 3, 369394.

Feldman, M. (2000). Location and Innovation: The New Economic Geography of Innovation, Spillovers, and Agglomeration, in Clark G, Feldman M and Gertler M (eds), The Oxford handbook of economic geography, 373-394. Frenken, K., Ponds, F. and Van Oort, F. (2010).The citation impact of research collaboration in science-based industries: A spatial-institutional analysis.Papers in Regional Science, 89, 2, 351- 271.

Fujita, M. and Krugman, P. (2004). The New Economic Geography: Past, Present and the Future. Papers in Regional Science, 83, 1, 139-164.

Granberg, A., Masakova, I. and Zayceva, U. (1998).Gross regional product differentiation as an indicator of regional economic development (in Russian).Statistical Issues, 9, 3-11. 
Kireyeva \& Yespayev /International Journal of Research in Business and Social Sciences Vol3 , No1, 2014. ISSN: $2147-4478$

Hmeleva, G. (2012). Innovation development of the region: intensive and extensive way(in Russian).Problems of theory and practice of management, 7, 8, 45-56.

Kireyeva, A.A. and Nurlanova, N.K. (2013). The problems of spatial modernization of the economy and new approaches to way out from crisis: Kazakhstan's experience. Journal Distribution of Science, 11, 3, 39-48.

Koshkarov, A. V. (2012). Theoretical aspects of modelling and forecasting of development of the region on the basis of a limited array of statistical data (in Russian).Bulletin of ASTU, 1, 179-185.

Krugman, P. R. (1991).Increasing Returns and Economic Geography.Journal of Political Economy, The University of Chicago Press, 99, 3, 483-499.

Leontiev, V. (1997).Inter-Sector economy (in Russian). Moscow, Economics.

Maslennikova, N.A. (2010).Innovative susceptibility as the basis for the growth of innovation activity of company (in Russian).Collection of reports on the results of the international scientific-practical conference, Moscow, March 29 April 09.

Romer, P. (1986).Increasing Returns and Long Run Groft.Journal of Political Economy, 94, 5, 1002-1037.

Steiner, M. and Hartmann, C. (1998).Learning with clusters: a case study from Upper Styria.European Research in Regional Science, 8, 211-225.

Yespayev, S.S. and Kireyeva, A.A. (2013).Concept for formation and development of prospective national clusters(in Russian).Almaty, Institute of Economics.

Untura, G. (2012). Strategic support for the regions of Russia: problems of evaluation of the status of the territories of innovations(in Russian). Region: economy and sociology, 1, 123-141.

Utkin, E.amd Morozova, N. (1996). Innovation management (in Russian). Moscow.

Voronina, N.V. (1998).Investments in innovations as a basis for sustainable socio-economic development of the region(in Russian). Khabarovsk. 
Kireyeva \& Yespayev /International Journal of Research in Business and Social Sciences Vol3 , No1, 2014. ISSN: 2147-4478

APPENDIX A.

Initial data for calculation of innovative susceptibility regions of Kazakhstan in 2010

\begin{tabular}{|c|c|c|c|c|c|c|c|}
\hline No & $\begin{array}{l}\text { Region of } \\
\text { Kazakhstan }\end{array}$ & $\begin{array}{l}\text { GRP } \\
(\mathrm{mln} . \mathrm{KZT})\end{array}$ & $\begin{array}{l}\text { Labour } \\
\text { productivity, } \\
\text { (thnd. KZT/ } \\
\text { person) }\end{array}$ & $\begin{array}{l}\text { Employed } \\
\text { population, } \\
\text { (person) }\end{array}$ & $\begin{array}{l}\text { Fixedassets, } \\
(\mathrm{mln} . \mathrm{KZT})\end{array}$ & $\begin{array}{l}\text { Air } \\
\text { pollution } \\
\text { emissions, } \\
\text { (thnd. ton) }\end{array}$ & $\begin{array}{l}\text { Environmental } \\
\text { friendliness } \\
\text { production, } \\
\text { (thnd. KZT/ } \\
\text { per ton of emissions } \\
\text { of air pollutants) }\end{array}$ \\
\hline 1 & Akmolinsk region & 585965,4 & 1417,77 & 413300 & 834269,0 & 72,9 & 8037,9 \\
\hline 2 & Aktobe region & 1173592,9 & 2452,65 & 478500 & 1800713,0 & 125,3 & 9366,3 \\
\hline 3 & Almaty region & 997712,0 & 1183,53 & 843000 & 1119326,0 & 74,7 & 13356,3 \\
\hline 4 & Atyrau region & 2843649,2 & 11103,67 & 256100 & 4000862,0 & 97,8 & 29076,2 \\
\hline 5 & $\begin{array}{l}\text { West-Kazakhstan } \\
\text { region }\end{array}$ & 1048779,0 & 3323,13 & 315600 & 1854748,0 & 58,1 & 18051,3 \\
\hline 6 & Zhambyl region & 446399,3 & 3397,14 & 551300 & 498319,0 & 19,3 & 97038,5 \\
\hline 7 & Karaganda region & 1048779,0 & 633,82 & 704300 & 1644442,0 & 691,3 & 645,7 \\
\hline 8 & Kostanay region & 1872600,0 & 1673,33 & 512000 & 931813,0 & 114,5 & 7482,5 \\
\hline 9 & Kyzylorda region & 856747,0 & 2876,29 & 298700 & 992788,0 & 29,0 & 29625,8 \\
\hline 10 & Mangistau region & 859148,2 & 7211,50 & 205900 & 2111530,0 & 68,6 & 21645,0 \\
\hline 11 & $\begin{array}{l}\text { South-Kazakhstan } \\
\text { region }\end{array}$ & 1205298,0 & 1104,76 & 1091000 & 1126805,0 & 40,7 & 29614,2 \\
\hline 12 & Pavlodar region & 1031878,6 & 2485,86 & 415100 & 1418940,0 & 572,5 & 1802,4 \\
\hline 13 & $\begin{array}{l}\text { North-Kazakhstan } \\
\text { region }\end{array}$ & 466955,2 & 1303,98 & 358100 & 535270,0 & 77,8 & 6002,0 \\
\hline 14 & $\begin{array}{l}\text { East-Kazakhstan } \\
\text { region }\end{array}$ & 1244102,6 & 1713,40 & 726100 & 1346651,0 & 147,0 & 8463,3 \\
\hline 15 & Astana city & 1774185,2 & 4838,25 & 366700 & 2089306,0 & 56,1 & 31625,4 \\
\hline 16 & Almaty city & 3923412,6 & 5796,15 & 676900 & 4091076,0 & 11,0 & 356673,9 \\
\hline
\end{tabular}


Kireyeva \& Yespayev /International Journal of Research in Business and Social Sciences Vol3 , No1, 2014. ISSN: 2147-4478

Initial data for calculation of innovative activity regions of Kazakhstan in 2010

\begin{tabular}{|c|c|c|c|c|c|c|c|}
\hline No. & $\begin{array}{l}\text { Region of } \\
\text { Kazakhstan }\end{array}$ & $\begin{array}{l}\text { Research and } \\
\text { development } \\
\text { costs (mln. } \\
\text { KZT) }\end{array}$ & $\begin{array}{l}\text { Expenditure on } \\
\text { technological } \\
\text { innovation (mln. } \\
\text { KZT) }\end{array}$ & $\begin{array}{l}\text { Volume of } \\
\text { innovative } \\
\text { production } \\
(\mathrm{mln} . \mathrm{KXT})\end{array}$ & $\begin{array}{l}\text { Research and } \\
\text { development } \\
\text { costs } \\
\text { (KZT/per } \\
\text { person) }\end{array}$ & $\begin{array}{l}\text { Expenditure on } \\
\text { technological } \\
\text { innovation (KZT/ } \\
\text { per person) }\end{array}$ & $\begin{array}{l}\text { Innovative } \\
\text { production } \\
\text { output } \\
\text { per capita } \\
\text { (KZT/per } \\
\text { person) }\end{array}$ \\
\hline 1 & Akmolinsk region & 574,5 & 629,5 & 6959,6 & 1390,03 & 1523,11 & 9467,34 \\
\hline 2 & Aktobe region & 627,3 & 25667,3 & 9799,3 & 1310,97 & 53641,17 & 12833,60 \\
\hline 3 & Almaty region & 705,1 & 36,4 & 521,0 & 836,42 & 43,18 & 283,75 \\
\hline 4 & Atyrau region & 2199,3 & 323,8 & 126,1 & 8587,66 & 1264,35 & 242,04 \\
\hline 5 & $\begin{array}{l}\text { West-Kazakhstan } \\
\text { region }\end{array}$ & 212,9 & 415,9 & 8999,0 & 674,59 & 1317,81 & 14903,25 \\
\hline 6 & Zhambyl region & 1221,9 & 10447,9 & 723,8 & 2216,40 & 18951,39 & 699,67 \\
\hline 7 & Karaganda region & 939,4 & 2204,1 & 14897,7 & 1333,81 & 3129,49 & 11061,47 \\
\hline 8 & Kostanay region & 214,7 & 33,3 & 12453,0 & 419,34 & 65,04 & 14097,74 \\
\hline 9 & Kyzylorda region & 80,7 & 17760,0 & 1966,9 & 270,17 & 59457,65 & 2854,68 \\
\hline 10 & Mangistau region & 3064,8 & 7541,0 & 233,2 & 14884,90 & 36624,58 & 463,40 \\
\hline 11 & $\begin{array}{l}\text { South-Kazakhstan } \\
\text { region }\end{array}$ & 450,7 & 8504,9 & 4859,9 & 413,11 & 7795,51 & 1934,98 \\
\hline 12 & Pavlodar region & 198,8 & 10808,0 & 72592,0 & 478,92 & 26037,1 & 97526,11 \\
\hline 13 & $\begin{array}{l}\text { North-Kazakhstan } \\
\text { region }\end{array}$ & 112,1 & 325,4 & 2880,6 & 313,04 & 908,68 & 4859,82 \\
\hline 14 & $\begin{array}{l}\text { East-Kazakhstan } \\
\text { region }\end{array}$ & 5099,6 & 139824,7 & 13854,5 & 7023,28 & 192569,48 & 9910,28 \\
\hline 15 & Astana city & 4445,6 & 9,9 & 72,2 & 12123,26 & 27,0 & 111,22 \\
\hline 16 & Almaty city & 13319,8 & 2996,0 & 12686,6 & 19677,65 & 4426,06 & 9122,45 \\
\hline
\end{tabular}


Kireyeva \& Yespayev /International Journal of Research in Business and Social Sciences Vol3 , No1, 2014.

ISSN: 2147-4478

APPENDIX B.

Initial data for calculation of innovative susceptibility regions of Kazakhstan in 2012

\begin{tabular}{|c|c|c|c|c|c|c|c|}
\hline No. & $\begin{array}{l}\text { Region of } \\
\text { Kazakhstan }\end{array}$ & $\begin{array}{l}\text { GRP } \\
(\mathrm{mln} . \mathrm{KZT})\end{array}$ & $\begin{array}{l}\text { Labour } \\
\text { productivity, } \\
\text { (thnd. KZT/ } \\
\text { person) }\end{array}$ & $\begin{array}{l}\text { Employed } \\
\text { population, } \\
\text { (person) }\end{array}$ & $\begin{array}{l}\text { Fixedassets, } \\
(\mathrm{mln} . \mathrm{KZT})\end{array}$ & $\begin{array}{l}\text { Air } \\
\text { pollution } \\
\text { emissions, } \\
\text { (thnd. ton) }\end{array}$ & $\begin{array}{l}\text { Environmental } \\
\text { friendliness } \\
\text { production, } \\
\text { (thnd. KZT/ } \\
\text { per ton of } \\
\text { emissions } \\
\text { of air pollutants) }\end{array}$ \\
\hline 1 & Akmolinsk region & 809400,6 & 1934,05 & 418500 & 899290,0 & 77,8 & 10403,6 \\
\hline 2 & Aktobe region & 1477682,0 & 3735,29 & 395600 & 2058141,0 & 119,7 & 12344,9 \\
\hline 3 & Almaty region & 1246208,6 & 1386,22 & 899000 & 1204304,0 & 73,4 & 16978,3 \\
\hline 4 & Atyrau region & 3447336,7 & 12815,38 & 269000 & 4222539,0 & 107,3 & 32128,0 \\
\hline 5 & $\begin{array}{l}\text { West-Kazakhstan } \\
\text { region }\end{array}$ & 1323537,6 & 4189,74 & 315900 & 2105049,0 & 56,0 & 23634,6 \\
\hline 6 & Zhambyl region & 634251,9 & 1138,69 & 557000 & 600033,0 & 25,0 & 25370,1 \\
\hline 7 & Karaganda region & 2397919,6 & 3423,64 & 700400 & 1896112,0 & 691,3 & 3468,7 \\
\hline 8 & Kostanay region & 1135574,0 & 2214,46 & 512800 & 1033699,0 & 109,4 & 10380,0 \\
\hline 9 & Kyzylorda region & 1034819,0 & 3244,96 & 318900 & 1063848,0 & 31,9 & 32439,5 \\
\hline 10 & Mangistau region & 1751142,2 & 7687,19 & 227800 & 2336639,0 & 75,8 & 23102,1 \\
\hline 11 & $\begin{array}{l}\text { South-Kazakhstan } \\
\text { region }\end{array}$ & 1507227,9 & 1334,07 & 1129800 & 1361412,0 & 47,1 & 32000,6 \\
\hline 12 & Pavlodar region & 1527256,2 & 3651,98 & 418200 & 1616706,0 & 632,2 & 2415,8 \\
\hline 13 & $\begin{array}{l}\text { North-Kazakhstan } \\
\text { region }\end{array}$ & 667893,3 & 1928,66 & 346300 & 577290,0 & 77,0 & 8673,9 \\
\hline 14 & $\begin{array}{l}\text { East-Kazakhstan } \\
\text { region }\end{array}$ & 1624341,0 & 2262,63 & 717900 & 1554283,0 & 147,2 & 11034,9 \\
\hline 15 & Astana city & 2090987,4 & 5570,03 & 375400 & 2500182,0 & 63,5 & 32928,9 \\
\hline 16 & Almaty city & 4896311,0 & 7002,73 & 699200 & 4370448,0 & 11,6 & 422095,8 \\
\hline
\end{tabular}


Kireyeva \& Yespayev /International Journal of Research in Business and Social Sciences Vol3 , No1, 2014. ISSN: 2147-4478

Initial data for calculation of innovative activity regions of Kazakhstan in 2012

\begin{tabular}{|c|c|c|c|c|c|c|c|}
\hline No. & $\begin{array}{l}\text { Region of } \\
\text { Kazakhstan }\end{array}$ & $\begin{array}{l}\text { Research and } \\
\text { development } \\
\text { costs (mln. } \\
\text { KZT) }\end{array}$ & $\begin{array}{l}\text { Expenditure on } \\
\text { technological } \\
\text { innovation ( } \mathrm{mln} \text {. } \\
\text { KZT) }\end{array}$ & $\begin{array}{l}\text { Volume of } \\
\text { innovative } \\
\text { production } \\
(\text { mln. KXT) }\end{array}$ & $\begin{array}{l}\text { Research and } \\
\text { development } \\
\text { costs } \\
\text { (KZT/per } \\
\text { person) }\end{array}$ & $\begin{array}{l}\text { Expenditure on } \\
\text { technological } \\
\text { innovation (KZT/ } \\
\text { per person) }\end{array}$ & $\begin{array}{l}\text { Innovative } \\
\text { production } \\
\text { output } \\
\text { per capita } \\
\text { (KZT/per } \\
\text { person) }\end{array}$ \\
\hline 1 & Akmolinsk region & 471,0 & 3951,6 & 9822,5 & 1125,45 & 9442,29 & 13431,56 \\
\hline 2 & Aktobe region & 628,1 & 31438,0 & 16880,9 & 1587,71 & 79469,16 & 21468,78 \\
\hline 3 & Almaty region & 1007,8 & 2923,4 & 5498,1 & 1121,02 & 3251,84 & 2879,49 \\
\hline 4 & Atyrau region & 3010,9 & 14447,2 & 1828,1 & 11192,94 & 53707,06 & 3366,67 \\
\hline 5 & $\begin{array}{l}\text { West-Kazakhstan } \\
\text { region }\end{array}$ & 353,7 & 47344,1 & 24804,9 & 1119,66 & 149870,53 & 40497,8 \\
\hline 6 & Zhambyl region & 198,2 & 11444,4 & 11251,8 & 355,83 & 20546,5 & 10655,11 \\
\hline 7 & Karaganda region & 1528,4 & 8809,9 & 14388,6 & 2182,18 & 12578,38 & 10594,65 \\
\hline 8 & Kostanay region & 250,6 & 709,1 & 12453,0 & 488,69 & 1382,8 & 14157,57 \\
\hline 9 & Kyzylorda region & 79,5 & 2911,4 & 2281,3 & 249,29 & 9129,51 & 3199,58 \\
\hline 10 & Mangistau region & 5150,9 & 648,9 & 618,6 & 22611,5 & 2848,55 & 1133,59 \\
\hline 11 & $\begin{array}{l}\text { South-Kazakhstan } \\
\text { region }\end{array}$ & 440,5 & 18648,9 & 15374,0 & 389,89 & 16506,37 & 5864,58 \\
\hline 12 & Pavlodar region & 385,6 & 7895,3 & 73279,0 & 922,05 & 18879,24 & 98084,59 \\
\hline 13 & $\begin{array}{l}\text { North-Kazakhstan } \\
\text { region }\end{array}$ & 102,3 & 184,9 & 1469,5 & 295,41 & 533,93 & 2517,99 \\
\hline 14 & $\begin{array}{l}\text { East-Kazakhstan } \\
\text { region }\end{array}$ & 4175,9 & 32926,1 & 33592,5 & 5816,83 & 45864,47 & 24078,92 \\
\hline 15 & Astana city & 9280,9 & 3416,1 & 1818,6 & 24722,7 & 9099,89 & 2447,97 \\
\hline 16 & Almaty city & 16287,6 & 7291,6 & 10601,4 & 23294,62 & 10428,49 & 7309,8 \\
\hline
\end{tabular}

